\title{
A GINÁSTICA COMO UMA OPÇÃO EXTRACURRICULAR NA ESCOLA
}

\author{
Laura R. Tostes*, Marco Antonio C. Bortoleto
}

\begin{abstract}
Resumo
A pesquisa objetivou a análise do ensino da Ginástica Acrobática (GACRO) como prática extracurricular no colégio Anglo Portal do Engenho em Piracicaba-SP, instituição que desenvolve essa prática desde 1999. Considerado um estudo de caso, a metodologia do estudo de campo inclui observações não-participantes e entrevistas semiestruturadas. O projeto destaca o desenvolvimento integral de seus alunos, estudantes do $2^{\circ}$ ao $9^{\circ}$ ano do ensino Fundamental. Vimos que o trabalho realizado tem na GACRO sua base gímnica (MERIDA, 2008), contudo a perspectiva demonstrativa visa ampliar a participação ao se apresentar em festivais. Consequentemente, a formalidade das regras esportivas que caracteriza a GACRO foi sendo flexibilizada de modo a ampliar a participação e a adequação do projeto as particularidades do âmbito escolar (BORTOLETO \& PAOLIELLO, 2017). Do mesmo modo, os princípios pedagógicos foram modificados e mostram uma atividade cotidiana similar a vista em grupos de Ginástica Para Todos (PAOLIELLO et al. 2014) e da intitulada Acrobacia Coletiva (ALMEIDA, 2016). O projeto tem enorme aceitação e pode integrar-se no cotidiano escolar, a partir de um projeto extracurricular.
\end{abstract}

\section{Palavras-chave:}

acrobacia coletiva;educação física escolar;pedagogia

\section{Introdução}

A Educação Física escolar tem como objetivo apresentar as práticas corporais, experienciando e refletindo sobre elas por meio de diferentes práticas pedagógicas (MARCASSA, 2004). Nesse contexto a presente pesquisa objetivou a análise do ensino da ginástica como prática extracurricular no colégio particular Anglo Portal do Engenho na cidade de Piracicaba-SP, instituição que desenvolve essa prática desde 1999. Segundo Araújo, Rocha e Bossle (2017), a Educação Física, hoje, se confunde com práticas de determinadas modalidades esportivas e, em sua maioria, o aprendizado dessas se restringe à regras e esquemas técnicos, apesar de a perspectiva educacional do esporte ser importante e permitir alguns benefícios físicos. Portanto, esta pesquisa concentra a atenção na ginástica, como uma pedagogia do gesto e da vontade (SOARES, 1998). Seguindo esse contexto, o presente estudo se foca na Ginástica Acrobática, modalidade reconhecida pela Federação Internacional de Ginástica (FIG), e que se configura pela execução de coreografias compostas de acrobacias individuais e, principalmente, coletivas, que combinam força, flexibilidade e equilíbrio a elementos de dança, saltos e giros (MERIDA; NISTA-PICCOLO; MERIDA 2008).

\section{Resultados e Discussão}

Considerado um estudo de caso, a metodologia do estudo de campo inclui observações não-participantes bem como duas entrevistas semiestruturadas com as professoras responsáveis. $O$ projeto destaca 0 desenvolvimento integral de seus alunos, estudantes do $2^{\circ}$ ao $9^{\circ}$ ano do ensino Fundamental. As aulas tem duração de 50 minutos, acontecem uma vez por semana e, nos pareceu que ao longo do ano os objetivos foram alcançados. Vimos que o trabalho realizado tem na GACRO sua base gímnica (MERIDA, 2008), contudo a perspectiva demonstrativa visa ampliar a participação ao se apresentar em festivais. Consequentemente, a formalidade das regras esportivas que caracteriza a GACRO foi sendo flexibilizada de modo a ampliar a participação e a adequação do projeto as particularidades do âmbito escolar (BORTOLETO \& PAOLIELLO, 2017). Observamos ainda que a ação das professoras, principalmente durante a elaboração das coreografias, ocorre na forma de "mediadoras" ao permitir que os mesmos participem ativamente do processo de criação. O referido processo criativo é norteado por um tema gerador, que culmina numa apresentação coletiva final. Dessa forma, entendemos que o projeto permite que seus participantes aprendam os elementos fundamentais da GACRO, ou melhor dito, da "acrobacia coletiva", oferecendo uma atividade que, como discute Almeida (2016), "escapa" das formalidades regulamentárias e que potencializa uma pedagógica inclusiva e que certamente contribui no processo educativo empreendido pela escola.

\section{Conclusões}

Parece que o sucesso do projeto deve-se, em grande medida, à dedicação das professoras, cuja pedagogia fundamenta-se na experiência construída por elas e ainda há necessidade de formação continuada na GACRO com ênfase no ambiente escolar. Há a flexibilização das regras e aproximação da Acrobacia Coletiva, ao notar-se que as professoras optaram por um formato similar ao da GPT, sem ter contato direto com a prática ou mesmo terem citado, visando a participação em festivais. $\mathrm{Na}$ escola, ambiente de reflexão, transformação e aprendizagem, a prática da GACRO é uma possível e interessante opção, mesmo que no contexto extracurricular.

MARCASSA, L. Metodologia do Ensino da Ginástica: novos olhares, novas perspectivas. Revista Pensa a Prática, Goiânia, v.7, n.2, p. 171-186, Jul./Dez. 2004

a Prática, Goiânia, v.7, n.2, p. 171-186, Jul./Dez. 2004.
ARAÚJO, S.N.; ROCHA, L.O.; BOSSLE, F. Os conteúdos de ensino da Educação Física escolar: um ARAÚJO, S.N.; ROCHA, L.O.; BOSSLE, F. Os conteúdos de ensino da Educação Física escolar: um
estudo de revisão nos periódicos nacionais da área 21. Motrivivência, Florianópolis/SC, v. 29, n. 51, p. estudo de revisão nos periódicos nacionais da área 21. Motrivivência, Florianópolis/SC, v. 29,
205-221, julho/2017.
SOARES, C. L. et al. Metodologia do Ensino de Educação Física. São Paulo: Cortez, 1992. SOARES, C. L. et al. Metodologia do Ensino de Educação Física. São Paulo: Cortez, 1992. MERIDA, F. V. Reflexões sobre a Pedagogia da Ginástica Acrobática. Dissertação (Mestrado em Educação Física) - Universidade São Judas Tadeu, São Paulo, 2008.

MERIDA, F.; NISTA-PICCOLO, V. MERIDA, M. Redescobrindo a Ginástica Acrobática. Movimento, Porto Alegre, v. 14, n. 02, p. 155-180, mai/ago de 2008.

BORTOLETO, M. A. C.; PAOLIELLO, E. (Org.) . Ginástica para Todos - Um encontro com a coletividade 1. ed. Campinas-SP: UNICAMP, 2017. v. 1. 248p . PAOLIELLO, E.; TOLEDO, E.; Ayoub, Eliana; BORTOLETO, M. A. C.; GRANER, L. P. Grupo Ginástico Unicamp 25 anos. 1. ed. Campinas: UNICAMP, 2014. v. 1. 288p.ALMEIDA, T. L. Composição Coreográfica Coletiva e Tematização como estratégias pedagógicas para o ensino/aprendizado da acrobacia coletiva. Dissertação (Mestrado em Educação Física) - Faculdade de Educação Física, Universidade Estadual de Campinas, Campinas, 157p., 2016. 